\title{
THE SPECTRUM OF WEED SPECIES AND FUNGAL PATHOGENS IN STANDS OF ALTERNATIVE FODDER CROP LOLIUM MULTIFLORUM VAR. WESTERWOLDICUM GROWING UP IN A DROUGHT-PRONE AREA IN THE CZECH REPUBLIC
}

\author{
Leoš Kadlček ${ }^{1}$, Eliška Nováková², Ivana Šafránková², Radovan Pokorný², \\ Pavel Horký ${ }^{3}$, Martin Jiroušek ${ }^{1}$, Jan Winkler ${ }^{1}$

\footnotetext{
${ }^{1}$ Department of Plant Biology, Faculty of AgriSciences, Mendel University in Brno, Zemědělská 1, 61300 Brno, Czech Republic

2 Department of Crop Science, Breeding and Plant Medicine, Faculty of AgriSciences, Mendel University in Brno, Zemědělská 1, 61300 Brno, Czech Republic

${ }^{3}$ Department of Animal Nutrition and Forage Production, Faculty of AgriSciences, Mendel University in Brno, Zemědělská 1, 61300 Brno, Czech Republic
}

Link to this article: https://doi.org/10.11118/actaun.2021.013

Received: 17. 7. 2020, Accepted: 21. 1. 2021

To cite this article: KADLČEK LEOŠ, NOVÁKOVÁ ELIŠKA, ŠAFRÁNKOVÁ IVANA, POKORNÝ RADOVAN, HORKÝ PAVEL, JIROUŠEK MARTIN, WINKLER JAN. 2021. The Spectrum of Weed Species and Fungal Pathogens in Stands of Alternative Fodder Crop Lolium Multiflorum Var. Westerwoldicum Growing up in a Drought-Prone Area in the Czech Republic. Acta Universitatis Agriculturae et Silviculturae Mendelianae Brunensis, 69(1): 127-137.

\begin{abstract}
Annual ryegrass (Lolium multiflorum var. westerwoldicum) is cultivated in various areas of the world as a feed for live stock. Efforts to improve the production of high-quality feed in the face of deepening climate change have increased the demand for growing non-traditional types of crops, including ryegrass. The aims of the research were to determine the spectrum of weed and fungal pathogen species and to assess dangerous species of weeds and pathogens which negatively affect forage crops of annual ryegrass grown in dry conditions. In 2018-2019 the occurrence of weeds and fungal pathogens of ryegrass was evaluated in field conditions. The assessed lands were located in dry climatic conditions of South Moravia (Czech Republic). The vegetation recording was done on phytosociological plots of $12 \mathrm{~m}^{2}$. A total of 57 weed species were identified in the plots, where 12 species were toxic and 16 species were undesirable. The most problematic weeds and poisonous species were: Aethusa cynapium, Datura stramonium, Equisetum palustre, Euphorbia helioscopia, Fumaria officinalis and Solanum nigrum, which can cause health problems if present in cattle feed. A pathogenic infection caused by Blumeria graminis, Puccinia graminis var. graminicola and P. coronata var. coronata, Gaeumannomyces graminis and Drechslera sp. was identified on the ryegrass plants in the experimental plots during the vegetation. Blumeria graminis was the most abundant, but it did not endanger the final feed. The data was processed by CCA analysis.
\end{abstract}

Keywords: weed, disease, forage crops, monitoring, plant protection 


\section{INTRODUCTION}

Intensification of agriculture leads to radical changes in the environment such as thicken out of a soil profile, shortage of microelements and organic part in the soil etc. These changes influence soil fertility, quality of plant products, genetic variability, soil erosion and water quality (Cerdan et al., 2010; Panagos et al., 2015). The world agriculture, including European agriculture, is sensitive to climate change, because it aims for production of commodities of high quality. Due to climate change, entire agricultural sectors are endangered, including feed production. The feed quality substantially differs among plant species. So it is important to have knowledge about particular variety and genus characteristics, resistance to pests and pathogens, contained substances etc.; this information allows cultivators to produce high quality forage crop and to reduce the risk of delayed or substandard crop harvest (King and Karoly, 2017; Berauer et al., 2020).

One way to reach required forage crops quality and, at the same time, react to the change of climatic conditions is to grow new or lesser-known forage crops with different environmental requirements, such as annual ryegrass (Lolium multiflorum var. Westerwoldicum), as a feed source for cattle (Ivany et al., 2002; Orlandini et al., 2008). Annual ryegrass is a very adaptable crop. It can be grown in different climatic conditions and on different soil types, with specific environmental benefits, in particular the ability to prevent wind and water erosion of the soil (Buono et al., 2011). However, ryegrass can be endangered by pests or pathogens or various species of weeds. According to Lechenet et al. (2017), systematic monitoring of harmful organisms/ plants (pests, diseases and weeds) in cultivated crops is the basis of integrated protection, which allows effective ways of their regulation.

The production of crops, including feed crops, is endangered mainly by weeds (Busi et al., 2013), and therefore a wide species spectrum is important for monitoring. Fast and correct identification and knowledge of population dynamic are essential for their regulation (Suter, 2017).

Except for weeds, crops are endangered by pathogens and pests. Grasses, including ryegrass, are mainly attacked by fungal and bacterial pathogens, and their natural resistance is often insufficient to secure the required quality and yield of forage crop (Humphreys et al., 2010). Some fungal pathogens are also producers of mycotoxins that can reduce resistance to other harmful organisms (Ball, 2007; Wiewióra, 2015) or negatively affect the quality of forage for cattle (Wiewióra, 2015).

The main aims of this work were to determine

1. the spectrum of weed species and weed infestation intensity,

2. the spectrum of fungal pathogens, or as the case may be, the intensity of infection of annual ryegrass grown in dry conditions and

3. to determine dangerous species of weeds and pathogens which negatively affect forage crops quality.

\section{MATERIALS AND METHODS}

The field experiments of the evaluation of the annual ryegrass variety 'Diplomat' took place in South Moravia (Czech Republic; Tab. I), on land of the agricultural company Rajhradice, during vegetation seasons of 2018 and 2019. These experiments were done under the climatic conditions which were $500 \mathrm{~mm}$ of total annual average precipitation and $9^{\circ} \mathrm{C}$ of annual average temperature. The soil on the plots is deep and it is located in very warm and dry climatic region, with good production abilities.

The monitoring of weeds and pathogens was carried out on 7 permanent plots $\left(12 \mathrm{~m}^{2}\right)$ of annual ryegrass. The occurrence of pathogens and their frequency of infection was always monitored during 4 terms in 2018: 10. 4., 11. 5., 13. 6., 3. 7., and 4 terms in 2019: 12. 4., 27. 5., 14. 6. and 28. 6. The occurrence of weeds was evaluated once per vegetation on 13. 6. 2018 and 14. 6. 2019. The days for monitoring were chosen with regard to the growth phase of annual ryegrass and the course of the weather (Fig. 1).

Weed plant monitoring was performed by using phytocenological images. The total vegetation cover and the cover of the found weed species were determined optically in percents. Scientific names of species were used according to the Pladias database (Chytrý et al., 2020).

Pathogen monitoring was carried out in the form of picking plant samples from experimental plots. Leaves and stalks that showed signs of infection in field conditions were collected in paper bags. Under laboratory conditions, samples were sorted into 3 groups. The first group contained samples attacked by powdery mildew (Blumeria graminis), the second group contained leaf samples that showed the presence of rust (Puccinia ssp.) and the third group contained leaves with symptoms of leaf spot.

I: Description of individual locations

\begin{tabular}{ccccc}
\hline Year & Coordinates & Altitude & Type of soil & Total area \\
\hline 2018 & $49^{\circ} 06^{\prime} 23.90^{\prime \prime N}, 16^{\circ} 38^{\prime} 21.20^{\prime} \mathrm{E}$ & $204 \mathrm{~m}$ a. s. l. & gleyic fluvisol & 11.05 ha \\
2019 & $49^{\circ} 05^{\prime} 15.96^{\prime \prime N}, 16^{\circ} 38^{\prime} 11.21^{\prime} \mathrm{E}$ & $186 \mathrm{~m}$ a. s. l. & fluvic phaeozem & 8.59 ha \\
\hline
\end{tabular}

Source: The Research Institute for Soil and Water Conservation, v.v.i, 2020 


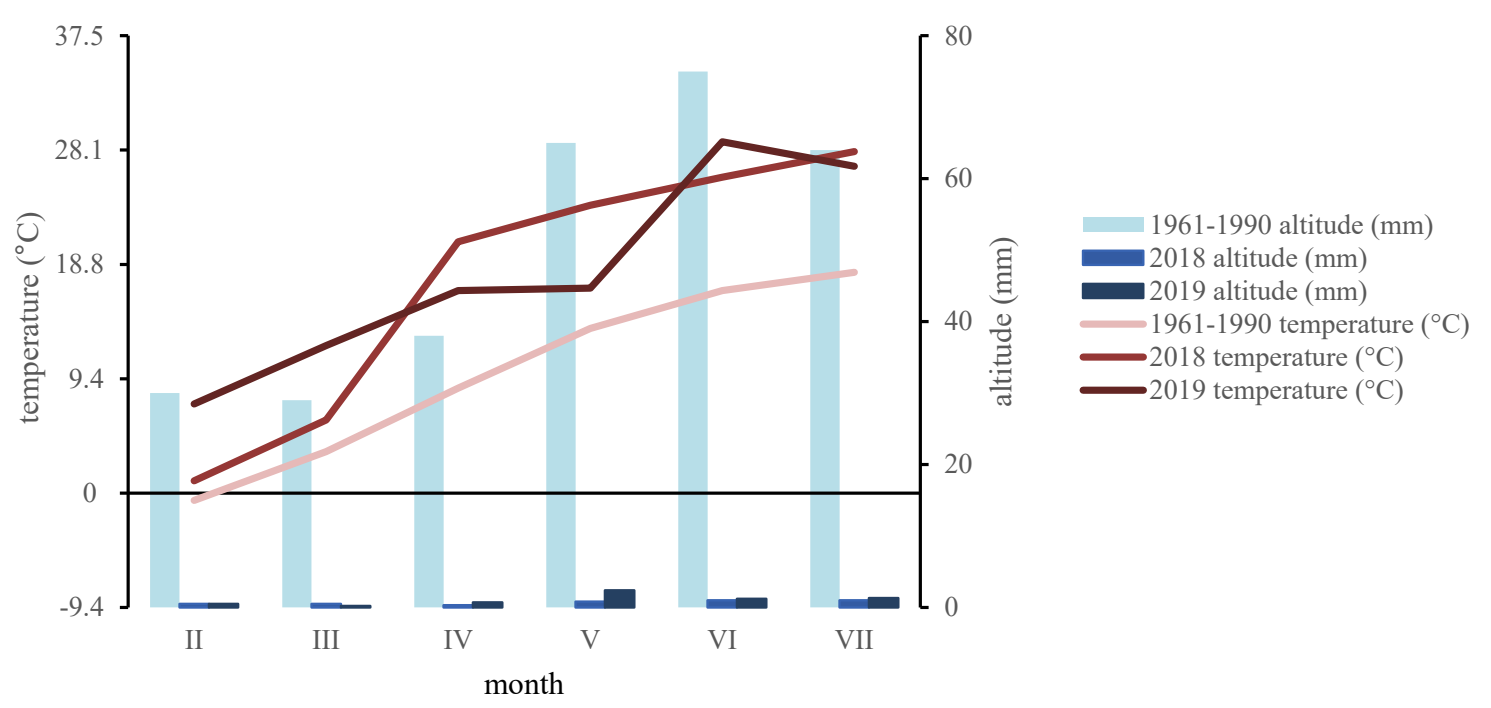

1: Average monthly temperature and total monthly precipitation during the vegetation of 2018 and 2019 (for Rajhradice location), in comparison with the long-term normal from 1961-1990

Source: network of agrometeorological stations TeranosALA, operator AMET Velké Bílovice, CHMI portal)

II: Modified scale for the evaluation of intensity of infection by powdery mildew according to Saari \& Prescott

\begin{tabular}{lcl}
\hline $\begin{array}{c}\text { Point value } \\
\text { of infested }\end{array}$ & $\begin{array}{c}\text { Percentage value } \\
\text { of indested (\%) }\end{array}$ & Description \\
\hline 1 & $75-100$ & The pathogen structures are located on almost the entire surface of the leaf area \\
2 & $50-75$ & The pathogen structures are located on more than half of the leaf area \\
3 & $20-50$ & The pathogen structures are located on almost one half of the leaf area \\
4 & $5-20$ & The pathogen structures are located on less than a quarter of the leaf area \\
5 & $0-5$ & The pathogen structures are located on almost one half of the leaf area \\
\hline
\end{tabular}

III: Modified scale for the evaluation of rust attack intensity according to Šebesta

\begin{tabular}{lcl}
\hline $\begin{array}{c}\text { Point value } \\
\text { of infested }\end{array}$ & $\begin{array}{c}\text { Percentage value } \\
\text { of indested (\%) }\end{array}$ & Description \\
\hline 1 & $<75$ & The pathogen structures are located on almost the entire surface of the leaf area \\
2 & $50-75$ & The pathogen structures are located on more than half of the leaf area \\
3 & $30-50$ & The pathogen structures are located on almost one half of the leaf area \\
4 & $15-30$ & The pathogen structures are located on less than a quarter of the leaf area \\
5 & $<15$ & The pathogen structures are located on almost one half of the leaf area \\
\hline
\end{tabular}

The Saari and Prescott (1975) rating scale was modified for samples infected with Blumeria graminis. For this scale, plants (samples) that do not show infection are evaluated with the number 5, while samples that are intensively infested by powdery mildew are evaluated with the number 1 .

Samples with the occurrence of rust were evaluated by a modified scale of infestation according to Šebesta (1991).

In the samples from the third group, the symptoms had low occurrence and the intensity of infection was not evaluated.

Leaf spots were observed under the microscope and the identification of pathogen's reproductive organs was performed on the basis of morphological structures. If it was not possible to identify the pathogen directly (its microscopic structures were not created), samples of the infected part of the plant were taken. The surface of these plants was then disinfected with $0.2 \%$ sodium hypochlorite solution, washed with distilled water (3 minutes), dried and cultivated in Petri dishes $(\varnothing 9 \mathrm{~cm})$ on two layers of filter paper moistened with distilled water. Cultivation was carried out under standard laboratory conditions $\left(20 / 25^{\circ} \mathrm{C}\right.$, lighting $14 / 10$ hours) for one week. Pathogens were identified based on microscopic observation of morphological structures. Some microscopic structures were 
isolated and cultured on medium - PDA or SA (Dehydrated culture media, potato dextrose agar by MP Biomedicals, Sabouraud dextrose agar by VWR, part of Avantor) to identify a particular species of pathogen. Cultivation on medium was performed under normal laboratory conditions for 7-10 days at laboratory temperature of $20 / 23^{\circ} \mathrm{C}$ and light regime of 14/10 hours.

Statistical data processing (monitoring of weeds and pathogens) was performed using multidimensional analysis of ecological data. Data was processed by DCA (Detrended Correspondence Analysis) to calculate the length of the gradient (Length of Gradient). Subsequently Canonical Correspondence Analysis (CCA) was used. This way the cover of the found weed species was evaluated, and the cover of annual ryegrass was used as a factor of environment. The intensity of infection of fungal pathogens was processed by multivariate analysis of ecological data. The day of evaluation was used as an intermediate factor. Subsequently, redundancy analysis (RDA) was used.
Statistical significance testing was performed using the Monte-Carlo test and 999 permutations were calculated. The calculations were performed using the computer program Canoco 5.0. (Ter Braak and Šmilauer, 2012).

\section{RESULTS}

\section{Results of Weed Evaluation in the Annual Ryegrass Cover}

A total number of 57 weed species were found and identified during monitoring in 2018-2019 (Tab. IV). In 2018, a total number of 36 species were found and in 2019 it was a total number of 38 weed species. Tab. IV shows the representation of species (in \%) in both years. In 2018, the most common species were Anagallis arvensis, Datura stramonium, Chenopodium album, Oxalis fontana and Persicaria lapathifolia, in 2019 the most common species were Amaranthus retroflexus and Fallopia convolvulus.

For every kind of weed its significance was determined based on the relationship to forage

IV: Species composition of weeds (2018-2019) in the annual ryegrass stand, their average cover and their significance for forage crops

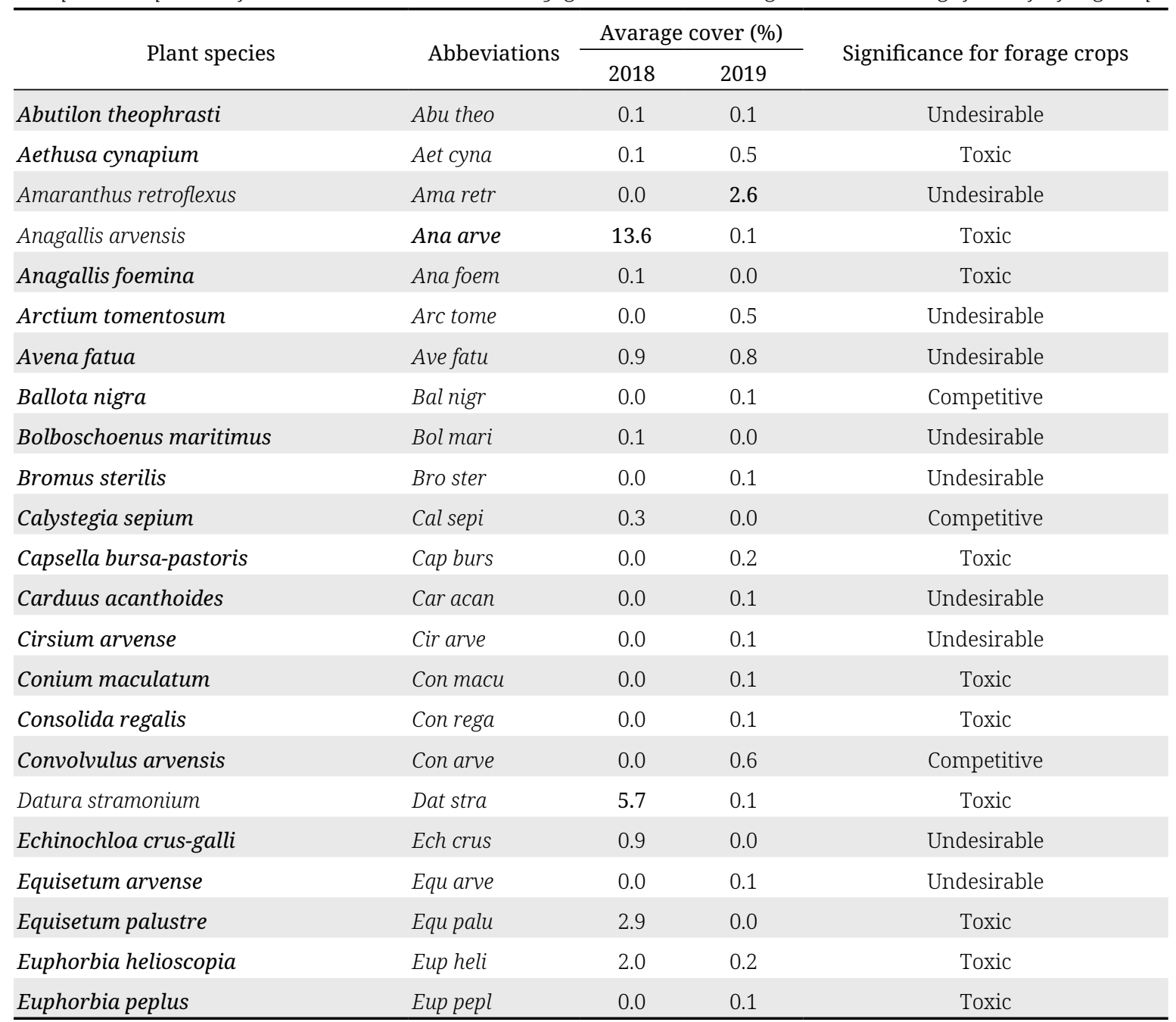




\begin{tabular}{|c|c|c|c|c|}
\hline \multirow{2}{*}{ Plant species } & \multirow{2}{*}{ Abbeviations } & \multicolumn{2}{|c|}{ Avarage cover (\%) } & \multirow{2}{*}{ Significance for forage crops } \\
\hline & & 2018 & 2019 & \\
\hline Fallopia convolvulus & Fal conv & 0.0 & 16.2 & Competitive \\
\hline Fumaria officinalis & Fum offi & 2.9 & 0.1 & Toxic \\
\hline Galium aparine & Gal apar & 0.0 & 0.3 & Undesirable \\
\hline Hordeum vulgare & Hor vulg & 0.0 & 0.4 & Undesirable \\
\hline Humulus lupulus & Hum lupu & 0.1 & 0.0 & Undesirable \\
\hline Chenopodium album & Che albu & 4.7 & 2.0 & Competitive \\
\hline Chenopodium hybridum & Che hybr & 1.3 & 0.0 & Competitive \\
\hline Chenopodium polyspermum & Che poly & 0.9 & 2.9 & Competitive \\
\hline Lamium purpureum & Lam purp & 2.1 & 1.0 & Competitive \\
\hline Linaria vulgaris & Lin vulg & 0.4 & 0.0 & Competitive \\
\hline Mentha arvensis & Men arve & 0.1 & 0.0 & Competitive \\
\hline Microrrhinum minus & мiс minu & 1.6 & 0.0 & Competitive \\
\hline Oxalis fontana & Oxa font & 10.0 & 0.0 & Competitive \\
\hline Papaver rhoeas & Pap rhoe & 0.0 & 0.1 & Competitive \\
\hline Persicaria amphibia & Per amph & 0.7 & 1.0 & Competitive \\
\hline Persicaria lapathifolia & Per lapa & 5.4 & 0.1 & Competitive \\
\hline Plantago major & Pla majo & 0.1 & 0.0 & Competitive \\
\hline Polygonum aviculare & Pol avic & 0.1 & 0.1 & Competitive \\
\hline Rorippa austriaca & Ror aust & 0.1 & 0.0 & Competitive \\
\hline Rubus sp. & Rub sp. & 0.0 & 0.1 & Undesirable \\
\hline Setaria pumila & Set pumi & 0.4 & 0.0 & Undesirable \\
\hline Silene latifolia & Sil lati & 6.7 & 0.0 & Competitive \\
\hline Silene noctiflora & Sil noct & 0.0 & 1.8 & Competitive \\
\hline Sinapis arvensis & Sin arve & 0.0 & 2.5 & Competitive \\
\hline Solanum nigrum & Sol nigr & 0.1 & 0.0 & Toxic \\
\hline Sonchus arvensis & Son arve & 1.1 & 0.0 & Competitive \\
\hline Stachys anпua & Sta annu & 0.1 & 0.0 & Competitive \\
\hline Stachys palustris & Sta palu & 1.7 & 0.0 & Competitive \\
\hline Symphytum officinale & Sym offi & 0.3 & 0.0 & Competitive \\
\hline Tripleurospermum inodorum & Tri inod & 0.1 & 0.1 & Competitive \\
\hline Triticum aestivum & Tri aest & 0.0 & 0.3 & Undesirable \\
\hline Veronica persica & Ver pers & 0.0 & 1.0 & Competitive \\
\hline Veronica polita & Ver poli & 3.0 & 0.6 & Competitive \\
\hline Viola arvensis & Vio arve & 0.7 & 1.2 & Competitive \\
\hline Lolium multiflorum var. westerwoldicum & & 36.9 & 76.5 & \\
\hline
\end{tabular}

production and quality. This is listed in the last column of Tab. IV. 12 species of weeds, which belong to the group of toxic species, and 16 species, which belong to the group of undesirable species, were found during the monitoring in the years 2018-2019. Undesirable species are defined as plants that are covered with trichomes, hooks, awns or those that contain high quantity of sclerenchymatic tissues, which can irritate the digestive system of cattle, or reduce the digestibility of forage.

Abbreviations for weed species are listed in Tab. IV; the vector designated LolMulAn is an expression of the coverage of L. multiflorum var. westerwoldicum, minimum was 13\% and maximum 90\%. 
The group of weeds shown in the ordination diagram in brown-beige color represents a group of weeds, which was found mainly in places of low cover of Lolium multiflorum. The species included in this group are: Abutilon theophrasti, Anagallis arvensis, Anagallis foemina, Bolboschoenus maritimus, Datura stramonium, Echinochloa crus-galli, Equisetum palustre, Euphorbia helioscopia, Fumaria officinalis, Chenopodium album, Chenopodium hybridum, Lamium purpureum, Mentha arvensis, Microrrhinum minus, Oxalis fontana, Persicaria lapathifolia, Plantago major, Polygonum aviculare, Rorippa austriaca, Setaria pumila, Silene latifolia, Sinapis arvensis, Solanum nigrum, Sonchus arvensis, Stachys annua, Stachys palustris, Tripleurospermum inodorum, Veronica polita.

The second group of weed species shown in ordination diagram in green represents species that occurred in places with lower to medium cover of Lolium multiflorum var. westerwoldicum. For species from this group, we can assume the greatest competitiveness against cultivated annual ryegrass. These species include: Amaranthus retroflexus, Avena fatua, Ballota nigra, Calystegia sepium, Cirsium arvense, Conium maculatum, Consolida regalis, Convolvulus arvensis, Equisetum arvense, Fallopia convolvulus, Hordeum vulgare, Humulus lupulus, Chenopodium polyspermum, Linaria vulgaris, Papaver rhoeas, Persicaria amphibia, Silene noctiflora, Symphytum officinale, Triticum aestivum, Veronica persica, Viola arvensis.

The third group of weed species shown in ordination diagram in blue represents species which were influenced by other factors than annual ryegrass cover. The occurrence of these species of weeds may be influenced by soil condition and its seed bank or by the method of soil treatment or also by the course of the weather in the monitored years. Representatives of this group are: Aethusa cynapium, Arctium tomentosum, Bromus sterilis, Capsella bursapastoris, Carduus acanthoides, Euphorbia peplus, Galium aparine, Rubus sp.

\section{Results of Evaluation of Pathogen Infection}

The first occurrence of Blumeria graminis was recorded on 10. 4. 2018. The pathogen was found on the field site at a similar frequency during subsequent observations on 11. 5. 2018 (Fig. 1). In June (13. 6. 2018), the vegetation was already strongly affected by the long-lasting drought (Fig. 1) and became dry. In addition to powdery mildew, rust uredospores were also found on the leaves (Tab. V). On the last date of observation (3. 6. 2018), teliospores (determining spores of rust) were found on dry blades. The correctness of the identification was verified in the laboratory by microscopic methods on the basis of morphological properties. The rust was identified as Puccinia coronata var. coronata and $P$. graminis var. graminis.

The total of 28 plant samples in which the presence of a pathogenic organism was suspected, were taken in 2018. Pathogens were identified in 25 samples. Powdery mildew (B. graminis) was present with the highest frequency.

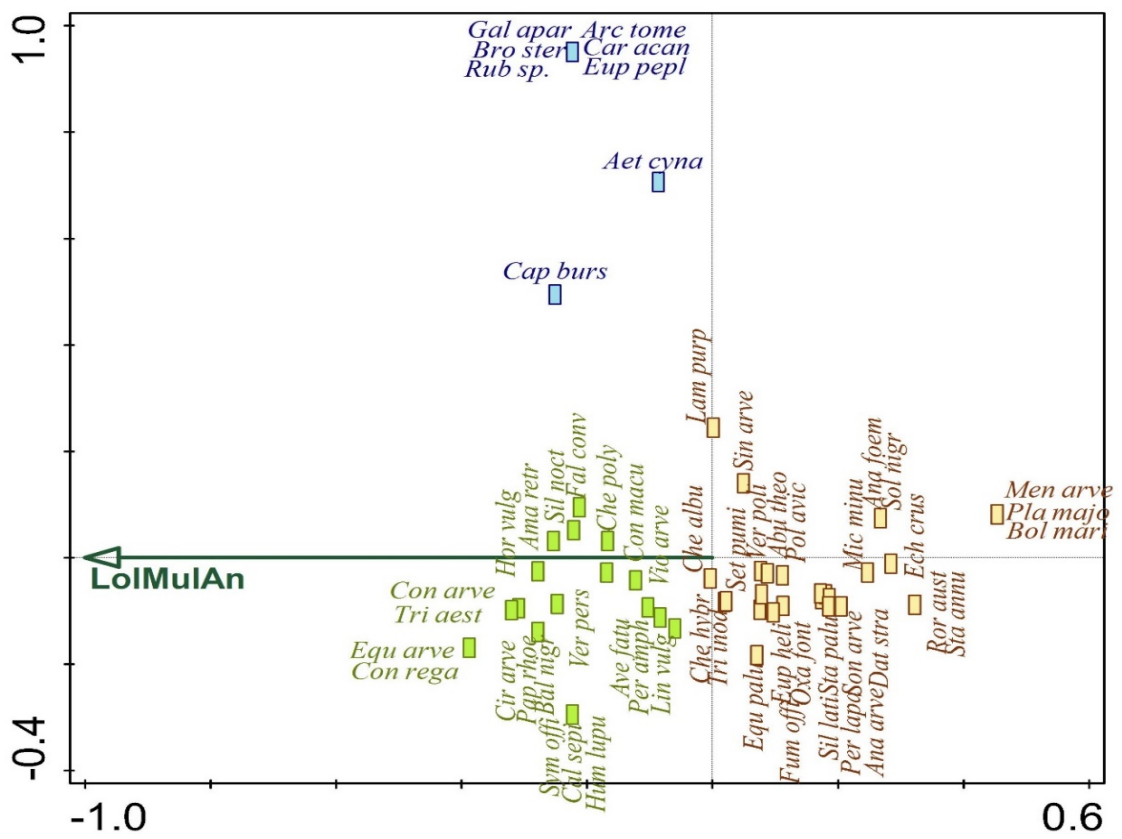

2: Ordination diagram expressing the relationship between the occurrence of selected weed species and the cover of annual ryegrass (L. multiflorum var. westerwoldicum) (CCA analysis results; explanatory variables 11.8\%; pseudo $F=2.0$; $p=0.006$ )

Explanations to Fig. 2: Abbreviations for weed species are listed in Tab. IV; the vector designated LolMulAn is an expression of the coverage of L. multiflorum var. westerwoldicum, minimum was $13 \%$ and maximum $90 \%$. 
V: The occurrence of pathogens in the annual ryegrass stand in 2018

\begin{tabular}{lcccc}
\hline \multicolumn{1}{c}{ Date } & 10.4. & 11.5. & 13.6. & 3.7. \\
\hline \multicolumn{1}{c}{ Pathogen } & $(+/-)$ & $(+/-)$ & $(+/-)$ & $+(-)$ \\
\hline $\begin{array}{l}\text { Blumeria graminis } \\
\text { Puccinia coronata var. coronata }\end{array}$ & + & + & + & - \\
Puccinia graminis var. graminis & - & - & + & + \\
+
\end{tabular}$+++$

Explanations to Tab. V: A signs (+/-) indicate whether the pathogen was/was not found in the annual ryegrass cover at the definite monitoring date

VI: The occurrence of pathogens in the annual ryegrass stand in 2019

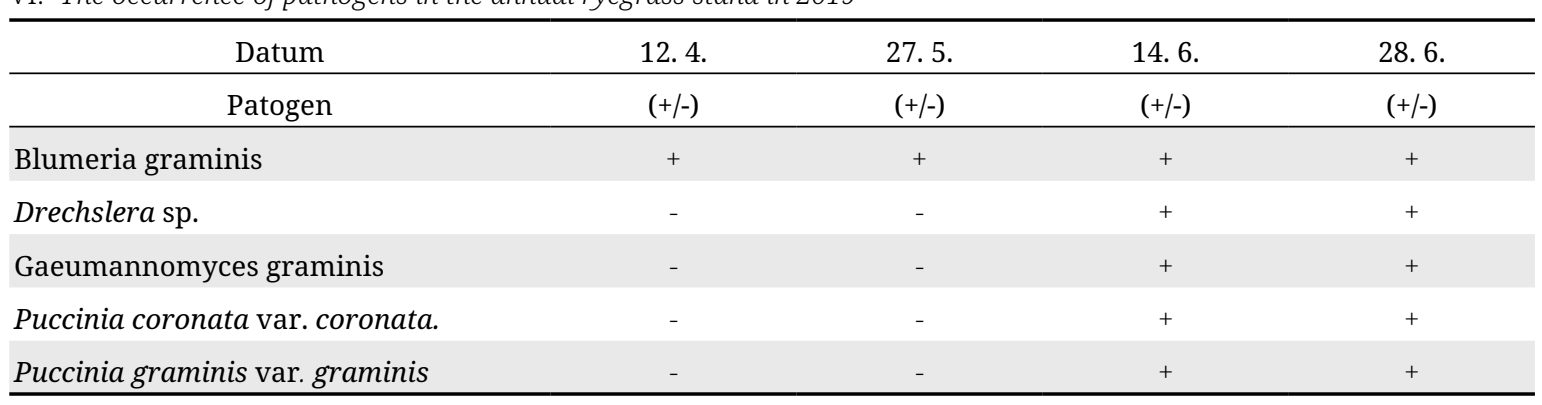

Explanations to Tab. VI: A signs (+/-) indicate whether the pathogen was/was not found in the annual ryegrass cover at the definite monitoring date

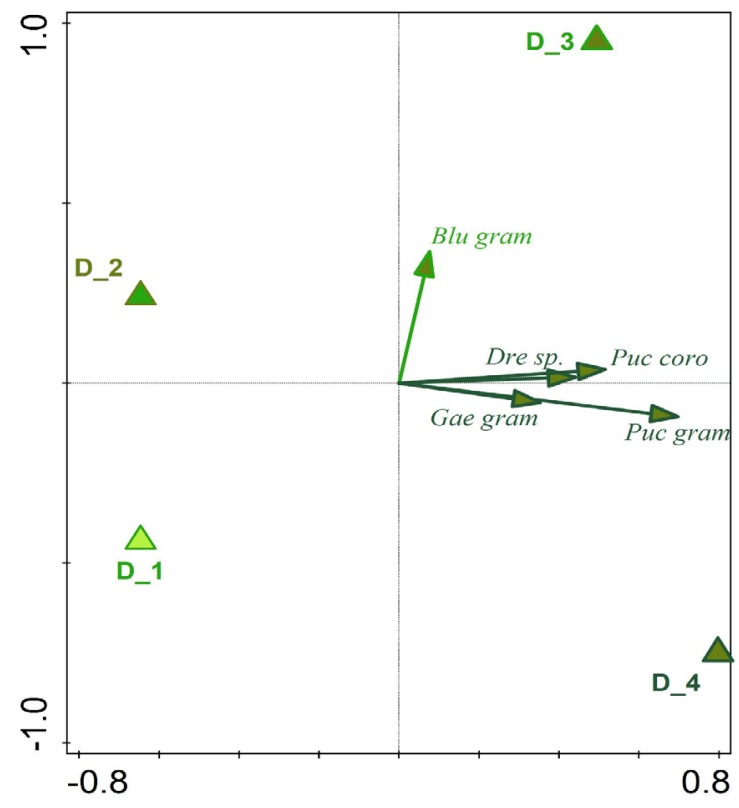

3: Ordination diagram expressing the relationship between the occurrence of diagnosed species of pathogens and monitoring terms of both years (RDA analysis results; explanatory variables 24.9\%; pseudo $F=7.1 ; p=0.001$ ) Explanations to Fig. 3: D_1-D_4 shows 1-4 term of annual ryegrass (L. multiflorum var. westerwoldicum) monitoring, during which the intensity of infection by fungal pathogens was evaluated.

In 2019, the start of vegetation was slow and for a long time the plants did not form a connected and compact cover. The first signs of mild infection with powdery mildew (B. graminis) occurred in the cover on 12. 4., but due to the cold and above-average rain in May the mass development of the pathogen did not happen (Fig. 1) and its occurrence was mild (27. 5.). In June (14. 6.), the occurrence of leaf spots was caused by the fungi Drechslera sp. and Gaeumannomyces graminis and rust (Tab. VI). They were microscopically determined as Puccinia coronata var. coronata and P. graminis var. graminis.

The total of 40 samples of plant parts were taken in 2019. Pathogens were found in 31 samples. A total of 5 species of pathogens were identified (Tab. VI). Low incidence of powdery mildew (B. graminis) was confirmed in 90\% of infected samples; this frequency did not adversely affect the quality of forage crop.

It is clear from the ordination diagram that all pathogens in the cover began their infection with the transition of the crop from vegetative to generative phase of development. The largest infection by powdery mildew (Blumeria graminis) occurred in the third term in both years (13. 6. 2018 and 14. 6. 2019). As the harvest date approached, the crop showed more intense infection, with the most pathogens at the highest frequency being observed in the fourth term of the 2019 evaluation, these were pathogens: $B$. graminis, Puccinia coronata var. coronata, $P$. graminis var. graminis, Drechslera sp., Gaeumannomyces graminis. Powdery mildew occurred in the cover in both years at the first monitoring dates, but the intensity of infection did not reach a level that could be assessed. 


\section{DISCUSSION}

The results show differences in the species spectrum of weeds in the monitored years (2018-2019). In contrast, the occurrence of fungal pathogens did not differ significantly during observation. Meteorological conditions play an important role for the growth and development of crops, but also of weed species and the occurrence of pathogens. The warm and dry weather of 2018 (Fig. 1), especially at the start of germination, was not favorable for the development of annual ryegrass. The growth in the first phase of development of cover showed differences in uneven presence of individual plants and relatively large gaps in the whole plot cover. The course of the weather fundamentally affected its competitiveness. It was not able to sufficiently suppress the pressure of weeds. On the other hand, drought and heat did not promote the development and production of pathogen spores. As a result, only 3 species of fungal pathogens were detected.

In 2019, the start of vegetation was slower again, but the plants significantly benefited from the May rainfall and showed $39.6 \%$ better coverage compared to 2018. Rapid growth of the annual ryegrass cover influenced the weed species composition. The weed cover was significantly lower compared to 2018. While there were fewer weed species in the total cover, in the case of pathogens, the different course of weather was reflected in their increased occurrence in terms of the number of their spectrum and the intensity of infestation. A total of 5 representatives of fungal pathogens were detected.

The harmfulness of weeds in fodder can manifest itself in various ways. In addition to the abovementioned competition for sources of water, nutrients or sunlight, directly in field conditions, they can cause a reduction of crop quality due to the content of alkaloids, glycosides, saponins, essential oils, resins, etc., which can be toxic to cattle and cause poisoning, or reduce the digestibility of fodder. The same is valid in the case of infection of forage crops by pathogens that can produce mycotoxins and thus reduce feed eatability.

Anagallis arvensis, which is considered an important field weed with high competitiveness in terms of nutrient and water uptake, was the most common in phytocenological relevés (Ogunmoyole et al., 2019). The plant is characterized by a lightly poisonous stem, the most poisonous substances are in the seeds, but due to the procumbent growth, it only gets to a limited concentration in the harvested forage. It is more dangerous for grazing livestock, especially cattle and sheep (Al-Sultan et al., 2003; Patočka and Frynta, 2008). Frequent animal poisoning is recorded especially in Australia, South and North America, India and Africa (Sadakat, 1995). Clinically, poisoning is manifested by weakness, faintness, coma, and death (Al-Sultan et al., 2003).
A non-toxic but abundant nitrophilous species (Alshallash, 2018) was the Chenopodium album, which is ranked among the ten most harmful weeds in the world (Gomaa, 2012). In 2019, the Fallopia convolvulus was significantly represented in the cover. According to Rezaul Karim (2002), in the case of an abundant occurrence, it can cause procumbent of the cover, which can lead to higher harvest losses and a reduction in forage quality.

Datura stramonium, containing $0.5 \%$ of the alkaloids of the tropane series in the leaves and seeds, as well as scopolamine, tannins, essential oils and coumarin derivatives (Miraldi et al., 2001), has been observed rarely in places with sparse cover of annual ryegrass. The alkaloids contained in the plant have an effect on the autonomic nervous system. Poisonings are manifested by visual disturbances, drying of the mucous membranes, general drowsiness and even coma. Horses and cattle react the most sensitively (Berkov et al., 2006). Plants reaching a height of up to 1 meter produce a considerable amount of seed capsules that get into the harvested forage. However, it does not find suitable conditions for growth in fully involved annual ryegrass cover, so the risk of poisoning is limited (Ally and Mohanlall, 2020).

In terms of content substances, the occurrence of Solanum nigrum, which contains the toxic alkaloids solanine and solanidine, accompanying saponins, tannins and nitrates, is also problematic in forage. The toxicity of these alkaloids depends on the growth phase of the plant, the soil type and the course of the weather during the vegetation. Solanum nigrum plants contain the most toxic substances during the period of green berries formation. Solanum nigrum contaminated corn silage leads to chronic poisoning in livestock, which is manifested by anorexia, diarrhea and reduced milk yield (Khan et al., 2018). Again, the annual ryegrass cover does not create favorable conditions for solanum and therefore it occurred only exceptionally in the monitored cover.

Other plant species can also cause problems if they occur in higher concentrations, for example Fumaria officinalis, containing isoquinolinies alkaloids (Edziri et al., 2020), which was found in the cover in 2019 only rarely, with only one of the species with a more frequent occurrence found in 2018. But even so, it was in such a low abundance on the annual ryegass cover that it was not dangerous for cattle. The ryegrass cover can be intensively weeded with Equisetum palustre, which occurs in places with higher groundwater levels. It contains the toxic piperidine alkaloid palustrine, which does not disappear even after drying (Tipke et al., 2019). It causes significant problems in grazing horses and endangers animals fed by feed. In 2018, it appeared on the land with a higher frequency. Occasionally, poisoning by the Aethusa cynapium, which contains the poisonous alkaloid cynapine, essential oils and other substances, can also occur. 
Poisoning is similar to Conium maculatum, only milder, but the consequences can be just as fatal (Shri et al., 2010). Toxicity of C. maculatum has been known since the Middle Ages. The alkaloid coniin causes poisoning of humans and animals (Vetter, 2004). The weed was not observed in the ryegrass cover in 2018 and in 2019, it represented only $0.1 \%$ of the cover on average (Tab. IV). In 2019, a small amount of Capsella bursa-pastoris was present, which according to Grosso et al. (2011) can lead to poisoning if the cover is heavily weeded.

Abutilon theophrasti and Bromus sterilis can be included among the types of weeds that reduce the digestibility of forage crops or limit its intake. The occurrence of Oxalis fontana was interesting since it is not a typical weed of cultivatable land (Oberlander et al., 2009). Annual ryegrass covers grown in new areas can create space for the spread of new weed species (Eslami, 2011).

The quality of forage crops can also be affected by pathogenic fungi through specific mechanisms, causing loss of yield and reduction of nutritional value. Some pathogens are producers of toxic secondary metabolites which can induce mycotoxicosis in animals. To date, approximately
300-400 mycotoxins have been identified (Smith et al., 2016), with only a few considered dangerous to livestock (Pereira et al., 2019; Ran et al., 2013). None of the identified pathogens are among their producers.

Besides mycotoxin production, pathogens can have detrimental effect on crop yield. The high intensity of infection of annual ryegrass by powdery mildew (Blumeria graminis) at the beginning of vegetation can reduce the yield by up to $25 \%$ due to a reduction in the size of the photosynthetically active leaf area (Trujillo et al., 2006). Powdery mildew, like grass rust, is an obligatory parasite that attacks many species of host plants (Zhang et al., 2005). The initial symptoms of infection in annual ryegrass (Lolium ssp.) are manifested by the formation of a whitish coating on the face of the lower leaf layers. The leaves turn brown and die. In terms of pathogen development and spread, optimal temperatures are $12-20^{\circ} \mathrm{C}$ (Marthe, 1982). The occurrence of powdery mildew and rusts on the monitored plots in the years 2018-2019 did not reach the intensity of infestation, which could negatively affect the quality of forage crop.

\section{CONCLUSION}

The forage of annual ryegrass (Lolium multiflorum var. westerwoldicum) is one of the possible alternatives for obtaining quality forage in the arid regions of Central Europe. Weeds and pathogens influence the quality of forage, they can reduce it or cause health problems for livestock. Among the weed species with a potentially negative effect on forage feed there were found Anagalis arvensis, Datura stramonium, Equisetum palustre, Fumaria officinalis, Euphorbia helioscopia, Aethusa cynapium and Solanum nigrum. The undesirable Avena fatua, Bolboschoenus maritimphus, Humulus lupulus and Symphytum officinaleor limit fodder intake due to the presence of awns, hooks and trichomes. All of the above mentioned weed species could cause poisoning and health problems in cattle if they are present in high concentration in feed. However, they were only present in small quantities on the monitored area and did not affect the quality of the forage. Although small amounts of poisonous or undesirable species regularly occur in annual ryegrass, it is important to pay attention to them. Among the fungal pathogens that were found, there was no species that would be a major producer of mycotoxins. Pathogenic fungi which were identified: Blumeria graminis, Drechslera sp., Gaeumannomyces graminis, Puccinia coronata var. coronata, Puccinia graminis var. graminis. The harvested crop, which was further processed for livestock consumption, was not adversely affected by their presence and was not dangerous to the animals.

The results show that the importance of the species spectrum of weeds and pathogens was not problematic for the production of annual ryegrass forage in the observed period. However, the occurrence of individual species of weeds and pathogens is also subject to change and is influenced by a number of factors, such as global climate change. Monitoring the occurrence of harmful organisms is therefore necessary in the oncoming years.

Further observations are necessary for the use of annual ryegrass (L. mutiflorum) in our geographical conditions for cattle nutrition. They will be focused on the subsequent determination of weeds and mycotoxins in the final forage.

\section{Acknowledgements}

The paper is an outcome of the project: AF-IGA-2018-tym001: Comparison of the impact of climate change on photosynthesis C3 and C4 plants cycles which are used in livestock feed. 


\section{REFERENCES}

ALLY, F. and MOHANLALL, V. 2020 An overview of tropane alkaloids from Datura stramonium L. Journal of Pharmacognosy and Phytochemistry, 9(3): 05-13.

ALSHALLASH, K. S. 2018. Germination of weed species (Avena fatua, Bromus catharticus, Chenopodium album and Phalaris minor) with implications for their dispersal and control. Annals of Agricultural Sciences, 63(1): 91-97.

AL-SULTAN, S. I., HUSSEIN, Y. A. and HEGAZY, A. 2003. Toxicity of Anagallis arvensis Plant. Pakistan Journal of Nutrition, 2(3): 116-122.

BALL, D. 2007. Forage Management and Grazing Strategies to Minimize Fescue Toxicosis. [Online]. Available at: http://www.4cattlemen.com/ncba2007/newsroom/RM104BallText.pdf Accessed: 2020, April 15].

BERAUER, B. J., WILFAHRT, P. A., REU, B. et al. 2020. Predicting forage quality of species-rich pasture grasslands using vis-NIRS to reveal effects of management intensity and climate change. Agriculture, Ecosystems \& Environment, 296: 106929.

BERKOV, S., ZAYED, R. and DONCHEVA, T. 2006. Alkaloid patterns in some varieties of Datura stramonium. Fitoterapia, 77: 179-182.

BUONO, D. and IOLI, G. 2011. Glutathione S-transferases of italian ryegrass (Lolium multiflorum): activity toward some chemicals, safener modulation and persistence of atrazine and fluorodifen in the shoots. J. Agric. Food Chem., 59(4): 1324-1329.

BUSI, R., NEVE, P. and POWLES, S. 2013. Evolved polygenic herbicide resistance in Lolium rigidum by low-dose herbicide selection within standing genetic variation. Evol. Appl., 6(2): 231-242.

CERDAN, O., GOVERS, G., LE BISSONNAIS, Y. et al. 2010. Rates and spatial variations of soil erosion in Europe: a study based on erosion plot data. Geomorhology, 122(1-2): 167-177.

CHYTRÝ, M., BUREŠ, P., DANIHELKA, J. et al. 2020. Paladias. [Online]. Available at: https://pladias.cz/ [Accessed: 2020, June 20].

CZECH INSTITUTE OF HYDROMETEOROLOGY. 2020. Climate characteristics maps; network of agrometeorological stations TeranosALA, operator AMET Velké Bílovice. ČHMI. [Online]. Available at: http://portal.chmi.cz/historicka-data/pocasi/mapy-charakteristik-klimatu [Accessed: 2020, June 15].

EDZIRI, H. et al. 2020. Phytochemical screening, antioxidant, anticoagulant and in vitro toxic and genotoxic properties of aerial parts extracts of Fumaria officinalis L. growing in Tunisia. South African Journal of Botany, 130: 268-273.

ESLAMI, S. V. 2011. Comparative germination and emergence ecology of two populations of common lambsquarters (Chenopodium album) from Iran and Denmark. Weed science, 59(1): 90-97.

GOMAA, N. H. 2012. Composition and diversity of weed communities in Al-Jouf province, northern Saudi Arabia. Saudi journal of biological sciences, 19(3): 369-376.

GROSSO, C. et al. 2011. Chemické složení a biologický screening Capsella bursa-pastoris. Revista Brasileira de Farmacognosia, 21(4): 635-643.

HUMPHEREYS, M., FEUERSTEIN, U., VANDEWALLE, M. and BAERT, J. 2010. Ryegrass. BOLLER, B., POSSELT, U. K. and VERONESI, F. (Eds.). Fodder Crops and Amenity Grasses, Handbook of Plant Breeding. Vol. 5. Springer Science + Business Media, pp. 211-260.

IVANY, J. A., LEA J., MCCULLY, K. V. and KUNELIUS, H. T. 2002. Herbicide effect on growth and seed production of Lolium multiflorum in Atlantic Canada. Crop protection, 21(10): 991-995.

KHAN, R. U., MEHMOOD, S. and KHAN S. U. 2018. Toxic effect of common poisonous plants of district bannu, khyber pakhtunkhwa. Pakistan J. Pharm. Sci., 31(1): 57-67.

KING, A. D. and KAROLY, D. J. 2017. Climate extremes in Europe at 1.5 and 2 degrees of global warming. Environmental Research Letters, 12(11): 114031.

LECHENET, M., DESSAINT, F., PY, G., MAKOWSKI, D. and MUNIER-KOLAIN, N. 2017 Reducing pesticide use while preserving crop productivity and profitability on arable farms. Nat Plants, 3: 17008.

MATHRE, D. E. 1982. Compendium of barley diseases. The American Phytopathological Society.

MIRALDI, E. et al. 2001. Distribution of hyoscyamine and scopolamine in Datura stramonium. Fitoterapia, 72(6): 644-648.

OBERLANDER, K. C. et al. 2009. A model of bulb evolution in the eudicot genus Oxalis (Oxalidaceae). Molecular Phylogenetics and Evolution, 51(1): 54-63.

OGUNMOYOLE, T. et al. 2019. Multiple organ toxicity of Datura stramonium seed extracts. Toxicology reports, 6: 983-989.

ORLANIDINI, S., FERRISE, R., MANCINI, M., ORLANDO, F., NATALI, F. and BINDI, M. 2008. Biomass production in hilly areas of central Italy. Proceedings of 10th Congress of the European Society of Agronomy. Italian Journal of Agronomy, 3(3): 491-492.

PANAGOS, P., BALLABIO, C., BORRELLI, P. et al. 2015. Rainfall erosivity in Europe. Sci. Total Environ., 511: 801-814. 
PATOČKA, J. and FRYNTA, J. 2008. Drchnička rolní - jedovatá i léčivá. Vesmír, 87: 577.

PEREIRA, C. S., CUNHA, S. C. and FERNANDES, J. O. 2019. Prevalent Mycotoxins in Animal Feed: Occurrence and Analytical Methods. Toxins, 11(5): 290.

RAN, R., WANG, C., HAN, Z., WU, A., ZHANG, D. and SHI, J. 2013. Determination of deoxynivalenol (DON) and its derivatives: Current status of analytical methods. Food Control, 34: 138-148.

THE RESEARCH INSTITUTE FOR SOIL AND WATER CONSERVATION, V.V.I. 2020. eKatalog BPEJ. [Online]. Available at: https://bpej.vumop.cz/30300 [Accessed: 2020, June 10].

REZAUL KARIM, S. M. et al. 2002. Competitive ability of different weed species. Pak. J. Agron., 1: 116118.

SAARI, E. E. and PRESCOTT, J. M. 1975. A scale for appraising the foliar intensity of wheat diseases. Plant Dis. Rep., 59(5): 377-380.

SADAKAT, M. 1995. Research of discharge application for environmental protection in Europe. J. Proc. Inst. Electrostat. Jpn., 19: 281.

SHRI, R., BHUTANI, K. K. and SHARMA, A. 2010. A new anxiolytic fatty acid from Aethusa cynapium. Fitoterapia, 81(8): 1053-1057.

SMITH, M. C., MADEC, S., COTON, E. and HYMERY, N. 2016. Natural Co-occurrence of mycotoxins in foods and feeds and their in vitro combined toxicological effects. Toxins, 8(4): 94.

SUTER, M., HOFER, D. and LÜSCHER, A. 2017. Weed suppression enhanced by increasing functional trait dispersion and resource capture in forage ley mixtures. Agriculture, ecosystems \& environment, 240(1): 329-339.

ŠEBESTA, J. 1991. Hodnocení chorob polních plodin z hlediska šlechtění na odolnost. Rostlinná výroba, 10: 23-24.

TER BRAAK, C. J. F. and ŠMILAUER, P. 2012. Canoco reference manual and user's guide: software for ordination (version 5.0). Ithaca: Microcomputer Power.

TIPKE, I. et al. 2019. HILIC HPLC-ESI-MS/MS identification and quantification of the alkaloids from the genus Equisetum. Phytochemical Analysis, 30(6): 669-678.

TRUJILLO, M., ALTSCHMIED, L., SCHWIZER, P., KOGEL, K. H. and HÜCKELHOVEN, R. 2006. Respiratory Burst Oxidase Homologue A of barley contributes to penetration by the powdery mildew fungus Blumeria graminis f.sp. hordei. J. Exp. Bot., 57(14): 3781-3791.

VETTER, J. 2004. Poison hemlock (Conium maculatum L.). Food and Chemical Toxicology, 42(9): 13731382.

WIEWIÓRA, B., ŻUREK, G. and ŻUREK, M. 2015. Endophyte-mediated disease resistance in wild populations of perennial ryegrass (Lolium perenne). Fungal Ecol., 15: 1-8.

ZHANG, Z., HENDERSON, C., PERFECT, E., CARVER T. L. W., THOMAS, B. J., SKAMNIOTI, P. and GURR, S. J. 2005. Of genes and genomes, needles and haystacks: Blumeria graminis and functionality. Mol. Plant Pathol., 6: 561-575. 
